\title{
Impacts of Neotectonics and Salt Diaper on the Nile Fan Deposit, Eastern Mediterranean
}

\author{
Amr Hamouda, Suzan El-Gharabawy* \\ Marine Geophysics Lab, National Institute of Oceanography and Fisheries, Alexandria 21556, Egypt
}

Corresponding Author Email: suzymooo@yahoo.com

https://doi.org/10.18280/eesrj.060102

Received: 5 January 2019

Accepted: 26 February 2019

\section{Keywords:}

neotectonics, subduction, Hellenic Arc,

Cyprean Arc, seismic strain, nile delta

\begin{abstract}
The Nile Delta is the largest clastic accumulation in the Mediterranean Sea and has been deposited within a region of significant Cenozoic tectonic activity. Therefore, it is important to evaluate the crustal thickness and seismic strain rate that impacts the Nile fan deposits; in conjunction with studying the interaction between salt tectonic and plate tectonics in this basin. Bouguer anomalies, crustal thickness and seismic strain were calculated using several equations.

The Eastern Mediterranean has gravity anomaly varied from -40 to $210 \mathrm{mGals}$ indicating the changing of the crustal thickness. The crustal thickness of the Hellenic Arc moving above Africa is faster than Turkey towards the Cyprus Arc. The movement variation between them is about $6 \mathrm{~mm} / \mathrm{y}$. This displacement distance is assumed to be achieved in about 10 million years. The seismic strain release is abruptly increase started from the Mediterranean Ridge towards the Aegean Sea where the maximum values located along the Hellenic Arc. Also, there are some clusters in the southern and northern Crete, which have high seismic strain release. The deformed fault-block movement is related to the impacts of strike-slip movements, growing salt diapirs.

The north-western side of the Nile deep fan deposit characterized by the formation of a series of salt folds and reverse faults above the Messinian evaporites which related to the compressional/subduction tectonics of the adjacent Mediterranean Ridge. These activities are associated with many clusters of mud volcanism along the southern part of the Hellenic and Cyprus arcs which separate both basins. The pre-Messinian sequences structures are related to a classic gravity-spreading deltaic tectonics. The structure reservoir along Nile delta effected and suffers from the subduction of the African plate beneath Eastern Europe and the impact of the salt tectonics.
\end{abstract}

\section{INTRODUCTION}

The seafloor of the eastern Mediterranean is characterized by a large Nile fan deposit which has bordered by arc-shaped and wide sedimentary deposit. It is more than $500 \mathrm{~km}$ long and 200-250 km wide. The Nile Delta has been deposited due to the influx of the Nile River sediments creating the biggest clastic accumulation in the Mediterranean Sea $[1,2]$. The Nile Delta composed of two pro-grading sedimentation systems separated by the major Messinian unconformity [3]. During the late Miocene the strait of Gibraltar was closed and the subsequent evaporation of the Mediterranean Sea water led to the deposition of thick salt layers (near the basin center) and forming many incised valleys on the shelf and slope [3-5]. The Messinian evaporate deposited layers played an important role in the structural evolution of the Nile Delta system. The western side of the Nile fan deposits is lying on the Herodotus Abyssal Plain at the base of the Egyptian margin south of Mediterranean Ridge faces [6]. Herodotus Abyssal Plain has a very narrow, flat-bottomed furrow and water depth averaging $2800 \mathrm{~m}$ (Figure 1).

The Mediterranean Ridge, has a typical marine accretionary prism with a thick pile (up to $12 \mathrm{~km}$ ) of off scrapped. It has an upper sedimentary cover, thick Upper Miocene/Messinian evaporitic sequences (locally up to $2 \mathrm{~km}$ ). The PlioceneRecent Nile Delta displays spectacular examples of complex thin-skinned tectonics that generally sole-out into the Messinian, with zones of both gravities spreading and/or gravity gliding [5].

The hydrocarbon seeps, mud volcanoes fluids and gas chimneys are located within the sub-salt layers at the Nile fan where the conduits are restricted to salt welds where the evaporites have vanished due to lateral gliding (thin-skinned tectonic) $[7,8]$.

The data of geophysical survey is a fundamental issue for our understanding of the tectonic hazards. The tectonic activity research will thus be helpful understand the impact of a single and/or group tectonic processes together as a part of evolution of the earth structure and the change of the crust thickness.

This study aims to estimate the crustal thickness and represent the seismic strain rate that impacts the fan deposit of the Nile delta, Eastern Mediterranean Region. In addition try to understand the interaction between thin-skinned salt tectonic and plate tectonics in these evaporites floored basins. 


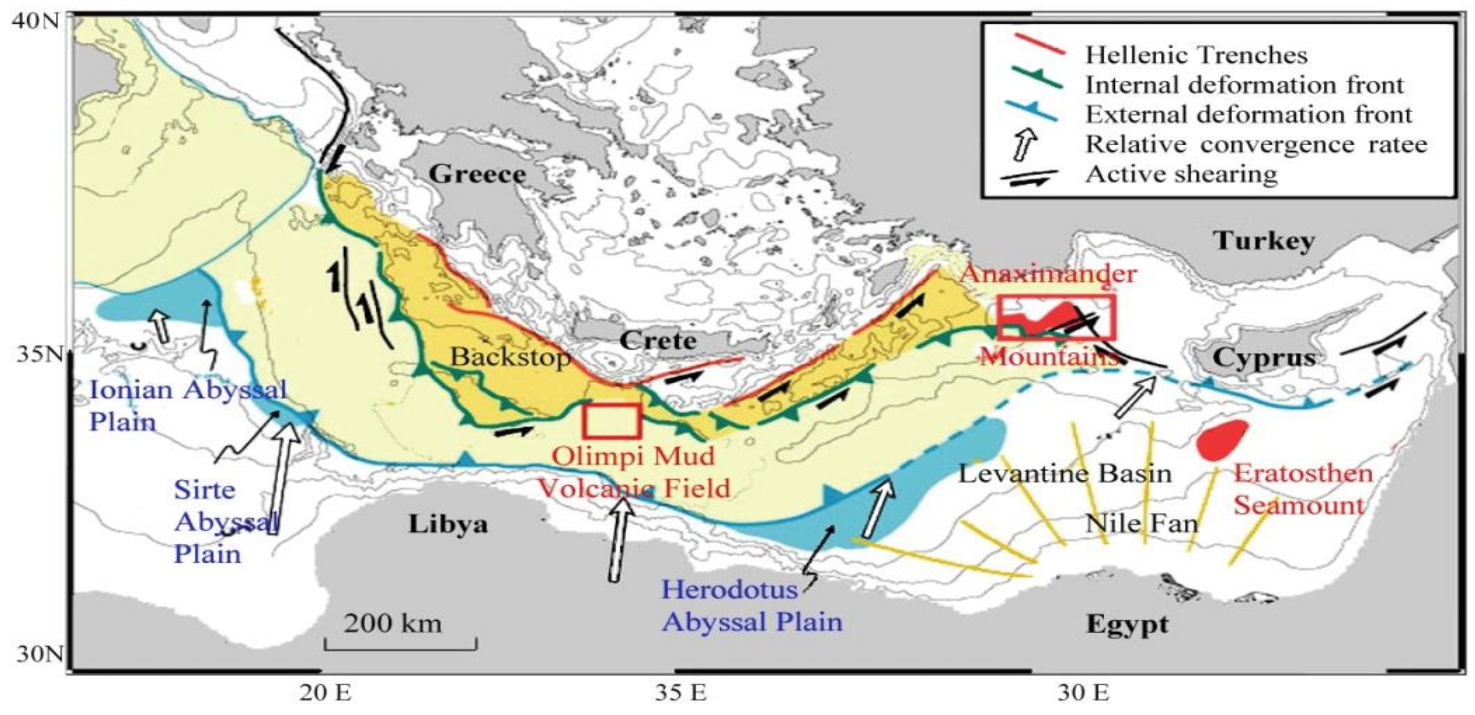

Figure 1. The morphological and structure scheme of the Eastern Mediterranean, on the right is the submenu of the second level operation [6]

\section{TECTONICS ACTIVITY}

This region has overpressure related to the subduction of the African plate beneath Eastern Europe which has results from the relatively rapid movement ( $>3 \mathrm{~cm} /$ year) [9-11]. In addition, because continental collision is progressive and diachronous, it is difficult to determine when, where and how collision has taken place but we can detect the hazards related to this collision (Figure 1). The subduction occurs in the central Mediterranean from $12 \mathrm{Ma}$ to present [12].

The deposited layers overlying the Messinian evaporates characterized by deltaic structures associated with salt movement such as folds, extensional and strike-slip faults, collapsed depocenters and polygonal mini-basins, as well as, listric growth faults and rotational block faulting [5, 7] (Figure 2). In contrast, the structures underneath the Messinian layers were characterized by deltaic tectonics results from gravity spreading and some evidence of basement-involved deformation $[4,13]$. The structures formed due to basement deformation in the Nile Delta had strike NW-SE (e.g. Temsah) and NE -SW (e.g. Rosetta) fault trends [13, 14] (Figure 2). The origin, nature and influence of these basement structures remain contentious. The NW-SE strike features were suggested to be related to structures primarily created during the deformation of Syrian Arc or old crustal conversions, while the NE-SW-striking features are hypothesized to be structures related to Mesozoic rifting and the north-westwards transition from continental to oceanic crust [15-17].

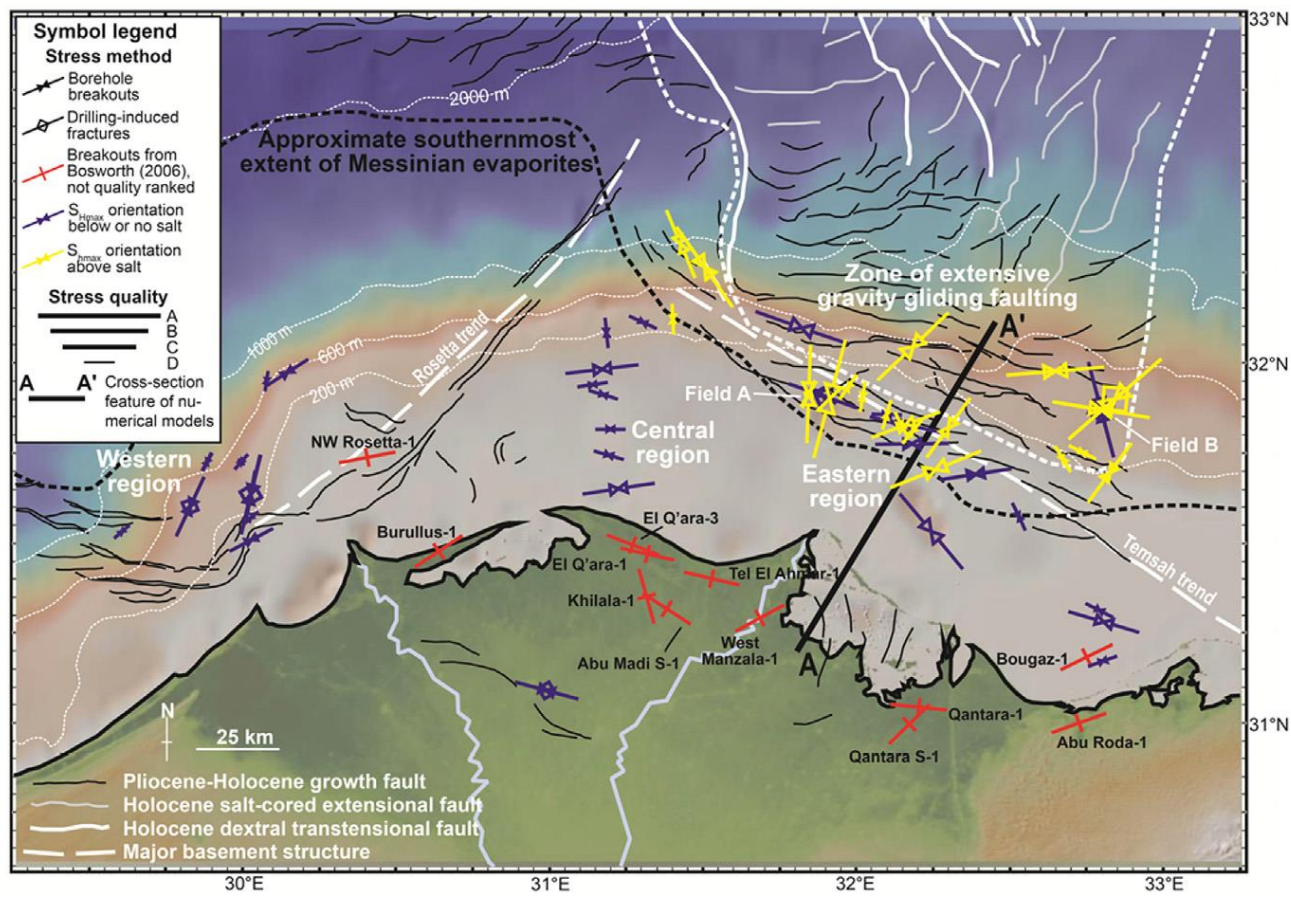

Figure 2. Map of the offshore Nile Delta [17] showing stress orientation data from the World Stress Map [18] and from [16]. Suprasalt stress data are shown in yellow, subsalt orientations in dark blue. The map also features the outline of the Messinian evaporites and the zone of gravitational gliding containing typical growth faults 
Structures in the sub-salt Nile Delta often appear to sole out into a hypothesized Oligocene-Late Cretaceous detachment horizon (most likely associated with over pressured shales), which may remove most of the influence of the basement on the stress field within the deltaic sequences [3, 17, 18] (Figure 2 ). In addition, the Nile Delta is located close to numerous plate boundary zones that may influence the stress pattern in the Nile Delta, including: the Cyprus Arc, particularly impingement of the Eratosthenes seamount; the Dead Sea Transform Fault Zone; and the Red Sea/Gulf of Suez Rift system $[19,20]$ (Figure 1). The overpressure affects the Nile Delta may be attributed to plate tectonics or from the evaporites load. The out flow of the fluids from the salt layers caused reduction in the volume and collapse of the sequences. Neotectonics refers to active stress regime that broadly from Miocene to Recent in the Eastern Mediterranean region.

The important of this region (the Nile Delta and Mediterranean deep water trend along the northern coastline of Egypt) related to an emerging giant oil \& gas (more than 50 trillion $\mathrm{cu} / \mathrm{ft}$ of gas) province situated ideally for markets in the circum-Mediterranean region. This explosive growth has been dominated by exploration for Pliocene age reservoirs shallower than $2,000 \mathrm{~m}$ below mud-line. This basin has sediments deposits that become the building blocks for petroleum systems [21, 22].

\section{AVAILABLE DATA}

The available Data that used during the study were the bathymetric data reveal from the International Bathymetric Chart of the Mediterranean (IBCM) project for the compilation of a bathymetric chart (IOC, 1981/1987). The data is represented as simplified bathymetric map (Figure 3) which has a $5 \mathrm{x} 5 \mathrm{~km}$ grid. The offshore gravity data of the Eastern Mediterranean countries were prepared in grid form by the Institute of Geophysics (IFG) of the University of Hamburg [23]. The marine gravity data were digitized from Cambridge Research Group [24] and from the OGS (Osservatorio Geofisico Sperimental, Trieste, Italy) profiles [25]. Makris [23] and Makris and Stobbe [26] give a detailed description of data along the Eastern Mediterranean. In this study the digital data which used from the Bouguer gravity sheet (IOC, 1988/1989) and Bouguer anomaly map of the Eastern Mediterranean Sea [27]. The data which digitize have an accuracy that permits interpretation to $5 \mathrm{mGal}$ isolines (Figure 4). The data which interpolated from the map is used for geological interpretation.

The earthquake data are collected from the NEIC catalog in the period between 1903 and 2015. Also, the deep seismic reflection and refraction information on the Mantle material or on the deeper Crust in the Eastern Mediterranean were carried out in 1971 by the Department of Geodesy and Geophysics, University of Cambridge, could reach a Moho velocity of 8.4 $\mathrm{km} / \mathrm{s}$.

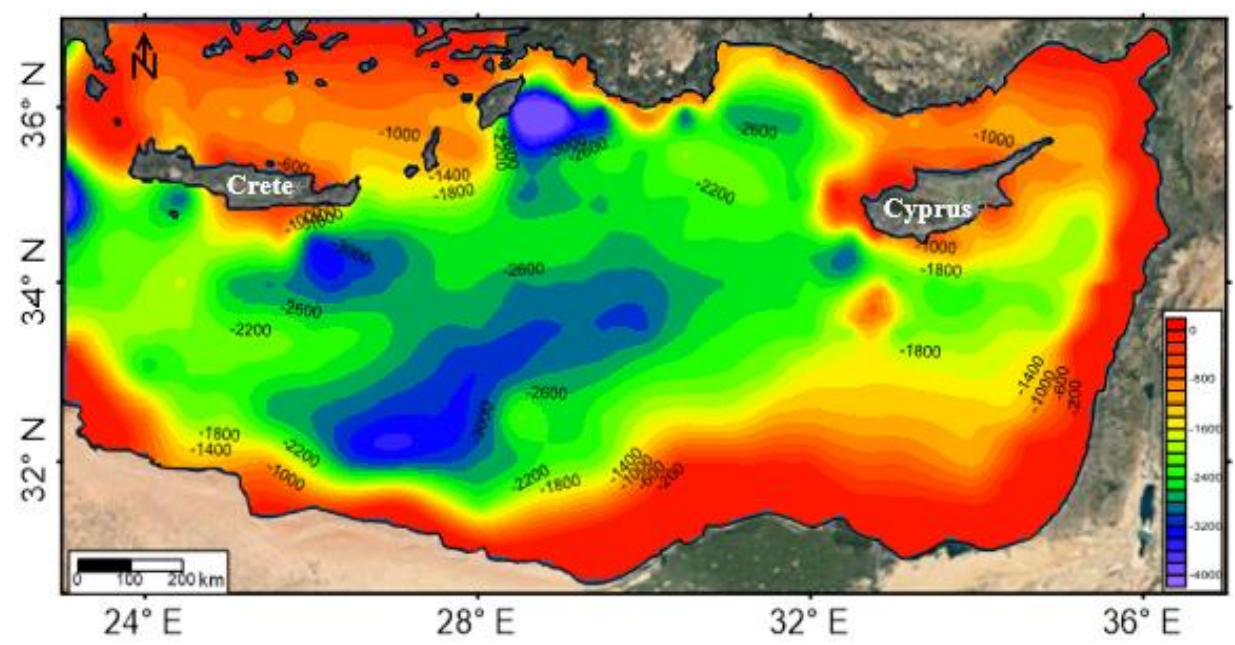

Figure 3. The result bathymetric map of the Eastern Mediterranean from the collected digitizing data (contour interval is $400 \mathrm{~m}$ )

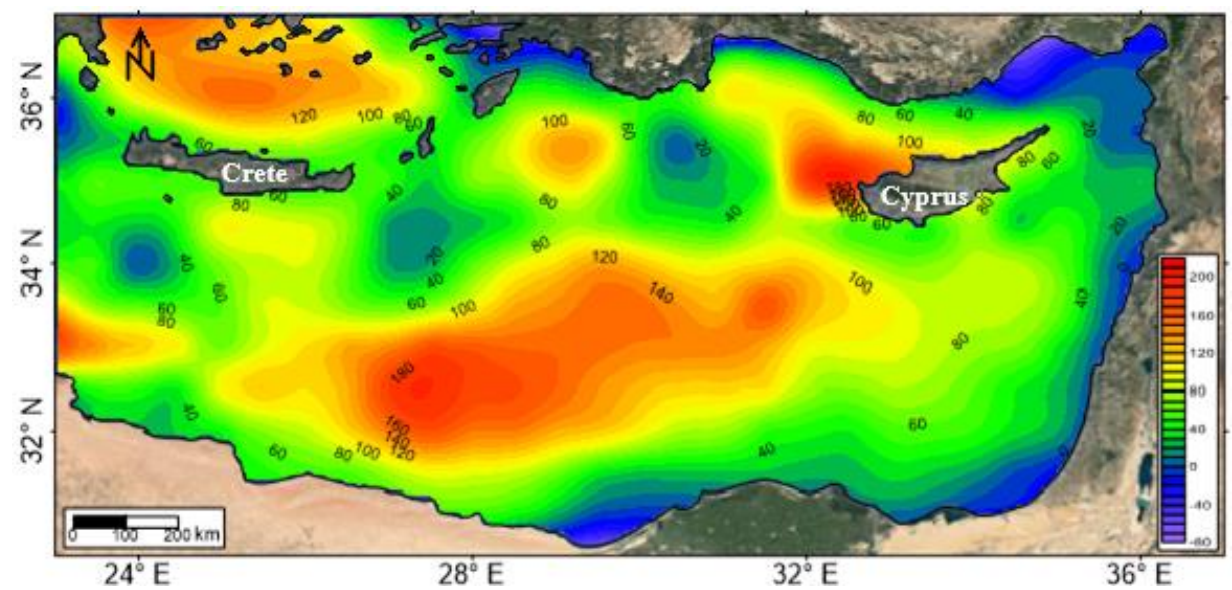

Figure 4. Bouguer gravity anomaly map of the Eastern Mediterranean Sea, Contour interval is 10 mgal 


\section{MATERIALS AND METHODS}

\subsection{Evaluation of the Bouguer Anomalies}

The gravity data that used in the study were processed and transformed into Bouguer anomalies. Then a qualitative interpretation of the anomalies was given and presented a typical two dimensional (2-D) density model that satisfy the bouguer gravity field of the different tectonic provinces of the Eastern Mediterranean Sea.

The Bouguer values were obtained by

$\Delta \mathrm{g}^{\prime \prime}=\delta \mathrm{g}^{\prime}-\delta \mathrm{g}_{\mathrm{t}}+\delta \mathrm{g}_{\mathrm{b}}$

$\boldsymbol{\delta} \mathbf{g}_{\mathbf{t}}=$ Terrain reduction with uniform density $2.67 \mathrm{~g} / \mathrm{cm}^{3}$. $\boldsymbol{\delta}_{\mathbf{b}}=$ Reduction of the Bouguer effect on spherical earth. [28].

The formula used for this computation was that of Spiegel

\subsection{Estimation of crustal thickness}

The crustal thickness along the North Nile Cone, Southern Crete and southern Cyprus was studied by using result data of seismic reflection and refraction experiments that was carried out in 1971 by the Department of Geodesy and Geophysics University of Cambridge and Moony et al. [29]. According to these studies, the Moho velociy in the Eastern Mediterranean could reach $8.4 \mathrm{~km} / \mathrm{s}$ especially in North Nile Cone. The deep seismic data show that the granitic layer $(5.0-6.7 \mathrm{~km} / \mathrm{s})$ presented everywhere so that a total thickness of $26-27 \mathrm{~km}$ of crustal material with velocities $3.5-6.7 \mathrm{~km} / \mathrm{s}$ seems to be presented everywhere in the Eastern Mediterranean [29]. Also by using the information of the 2-D density model [30] along the two seismic profiles, which has been further extend of 120 $\mathrm{km}$ offshore of northern Cyprus. All these available deep seismic profiles were used to obtain empirical relations between crustal thickness and Bouguer anomalies which can be applied on the Eastern Mediterranean. The Bouguer values are used for an average grid spacing of (5'x 5 ).

The correlation between the Bouguer anomaly and the depth to Moho discontinuity in the Eastern Mediterranean was carried out using regression analysis [28] and assuming a linear model of the subsurface medium. Gravity anomalies, of wavelengths $(\lambda)$ equal to 5 and 10 (i.e. digitized each $5 \& 10$ $\mathrm{km}$ grid spacing respectively), and the corresponding values of crustal thickness, for the two deep seismic refraction profiles one cross from Cyprus to North Africa and other southern Crete, were used for calculating the regression equation, standard deviation (SD) and correlation coefficients (r), by using Statgraph Program. Figure 5 shows the plot of the Bouguer anomalies versus the crustal thickness.

The empirical relations between the Bouguer anomalies $\left(\Delta \mathrm{g}_{\mathrm{B}}\right)$ and crustal thickness were found to be:

$\mathrm{Hc}=27.5-0.083 \Delta \mathrm{g}_{\mathrm{B}}$

For $\lambda=10 \mathrm{~km}$,

where: $\mathrm{SD}=5.65$ and $\mathrm{r}=-0.73$

and

$\mathrm{Hc}=28.2-0.081 \quad \Delta \mathrm{g}_{\mathrm{B}}$

for $\lambda=5 \mathrm{~km}$

where: $\mathrm{SD}=1.91$ and $\mathrm{r}=-0.62$

The values of "SD" and "r", show that equation (3) is more reliable for detailed mapping of the relief to Mohorovicic boundary in the study area.

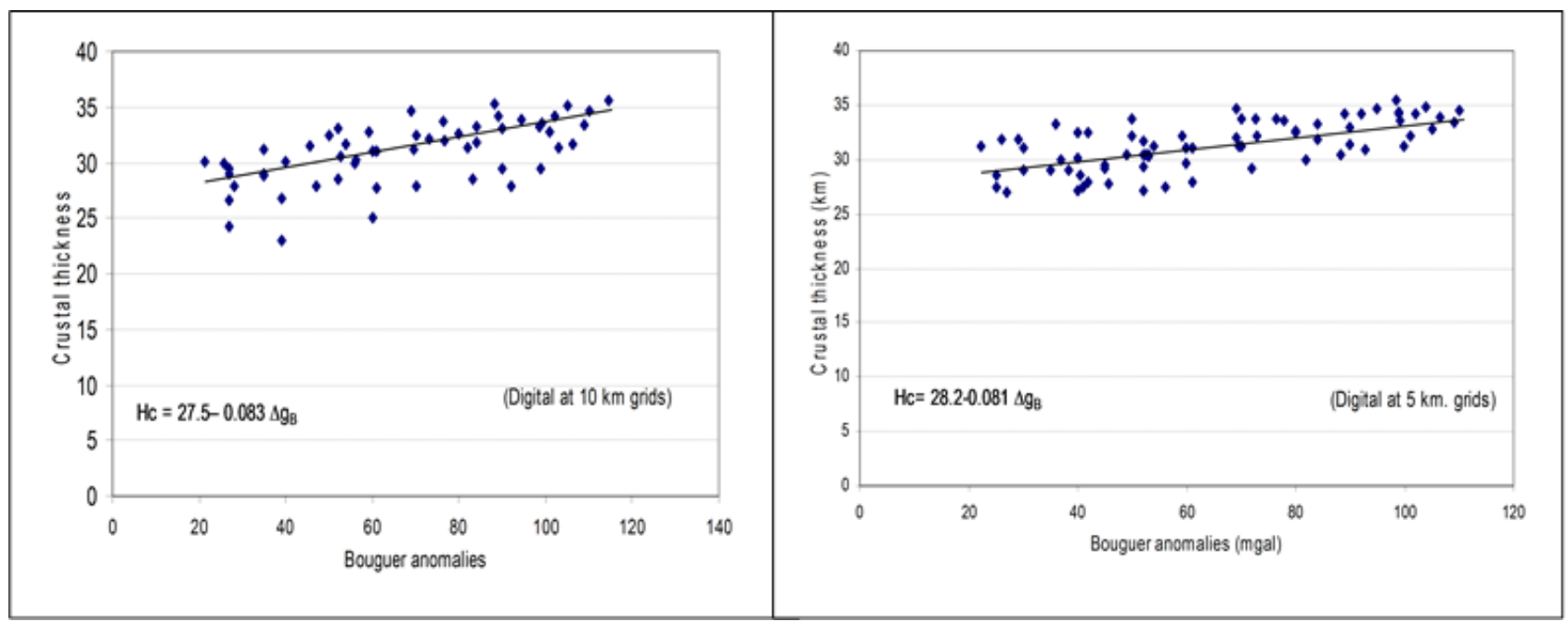

Figure 5. Relation between crustal thickness $(\mathrm{Hc})$ and Bouguer anomalies $\left(\Delta \mathrm{g}_{\mathrm{B}}\right)$ for the Eastern Mediterranean

\subsection{Seismic strain}

Seismic strain releases based on seismic event were used to determine active crustal deformation. It is significant for assessing seismic hazards. The calculation of the seismic strain is stand on the estimates of the scalar moment $M_{0}$ of the earthquakes, which is directly related to the seismic part of the strain [31]. An additional uncertainty arises because the relationship between magnitude and seismic moment exhibits regional variations [32]. The numbers of earthquakes are a function of the magnitude Ms in the study area, for magnitude between 4 and 8 .

The applied calculation method of seismic strain rate is described by kostrov [31] which gives a measure of the brittle deformation, which represent as:

$\mathrm{C}=(1 / 2 \mu v \Delta \mathrm{t}) \Sigma_{\mathrm{n}=1} M_{0}$ 
where $C$ is the strain rate, $v$ is the deforming volume, $\mu$ is the shear modulus, and $M_{0}$ is the seismic moment of the earthquake from the $\mathrm{N}$ total earthquakes occurring during the time interval $\Delta \mathrm{t}$. The seismic moment has been calculated according to Ekstrom and Dziewonski [32], using the surface magnitude, Ms:

$19.24+M s$

$\log M_{0}=30.2-(92.45-11.4 M s)^{1 / 2} \quad 5.3 \leq M s \leq 6.8$

$16.14+3 / 2 M s$

$M s>6.8$

\section{RESULTS AND DISCUSSIONS}

\subsection{Seafloor deformation}

The seafloor deformation is relevant to the deep tectonic but is complicated by the occurrence of surficial deformation and gravitational gliding due to the presence of salt layer underneath. Rather than an active subduction zone, the compressive tectonic setting appears to have developed into a wrenching system along the Hellenic and Cyprus Arcs. The seafloor mapping reveals a large network of conjugated faults, mainly thrusts and strike-slip faulting (Figure 3).

The seafloor level variation of the Eastern Mediterranean is mainly related to tectonic deformation along the Mediterranean Ridge, Hellenic and Cyprean Arcs, and surrounding margins, including the Nile Fan Deposit. The Eastern Mediterranean Sea represents a unique opportunity for studying the beginning of such a collision between the passive margins of Africa against the active margin of Europe. The maximum depth observed is about $3200 \mathrm{~m}$ in the Herodotus Abyssal Basin. The western side of Egypt to Cyrenaica is very step slop that may be related to the effect of the Mediterranean Ridge. In addition to the steep slopes that occurred in the southern of Cyprus and Crete that may be related to the effect of Cyprean and Hellenic Arcs. On the other hand, the gentle slopes were located in front of the Nile Delta of Egypt where the Nile Fan deposits accumulated (Figure 3).

The Mediterranean Ridge itself acts as a large accretionary prism between Africa and southern Europe. There are at least three recognizable main domains: the African continental slope to the south, the Southern Crete margin and bordering trench system to the north, and the Mediterranean Ridge in the middle. The data so far demonstrate clear differences in seafloor morphology and elevation and a strong contrast in structures.

\subsection{Bouguer map}

The Bouguer gravity map (Figure 4), shows that Eastern Mediterranean has gravity anomaly varied from -40 (southern margin of Anatolian) to 210 mGals (Herodotus Abyssal Plain). The slightly high gravity anomalies are lies in the Herodotus Abyssal Plain, Aegean Sea, Crete Sea, and North West of Cyprus nearly in between 140 and 180 mGals. This may indicates that the crust in these parts is probably thinner. Also, these parts are seemed to be highly active tectonics. Along the border of the continent (Africa, Asia, and European) the Bouguer anomaly changes to be negative values. This indicates that there is a sort of deep structure along this area and/or highly crustal thickness. The clusters which have abrupt changing in the gravity anomalies may be related to the changing in sediment thickness (i.e. between Cyprus and Crete); in addition to the changing of the crustal thickness and/or may be related to abrupt changing from continental to oceanic type (i.e. Aegean Sea).

\subsection{Crustal thickness}

The thickness of the crust varies approximately between 8 and $35 \mathrm{~km}$. The thinner crustal thickness of about $8-12 \mathrm{~km}$ is may found in the oceanic domains namely, Herodotus Abyssal Plain. The crust is thicker under the southern margin of Anatolian Peninsula which varies in between 30-35 km (Figure 6). Crete itself is positioned as an emergent high in the fore arc of the subduction system. North of the island, the topography quickly drops off into the thinned continental crust of the Cretan Sea. About $100 \mathrm{~km}$ north of Crete, the volcanic arc of the Hellenic Subduction Zone is located and represented by the island of Santorini [26]. In the Sea of Crete, the crust in the back-arc of the system is also attenuated continental crust [33].

Subduction involves the horizontal convergence of two tectonic plates; however, researchers have long recognized that wide spread extensional deformation is an evidence of the presence of subduction zones. The Hellenic subduction zone where the African plate dips to the north, deformation underlies the European plate has thinned the continental crust, forming the Aegean Sea. This subduction zone has outboard of volcanic arc along a thinned continental crust underlies the Sea of Crete. The Aegean Sea is generally considered as a back arc basin due to the aforementioned subduction [33]. Although most of the attenuated continental crust is now submerged, the islands of Crete and Cyprus provide a view of extensional deformation in the fore arc region at each side.

The concentration of the slab-pull force beneath Crete then drives rapid rollback as the African lithosphere sinks deeper into the mantle [34]. In fact, it is not possible to match the observed geodetic measurements in the Mediterranean without deep subduction and rapid rollback in the Hellenic Subduction zone [35]. The crust beneath the sea north of Crete, and the Aegean Sea is continental crust and typically about 20-24 km thick. Prior to deformation, the crust of the Aegean Sea has been estimated to be 1.5 to 2 times thicker than the current thickness [36].

In other words, we should rather analyze the Eastern Mediterranean plate tectonics in terms of both absolute motions, and relative motions of eastern and western parts (Hellenic and Cyprean Arcs) relative to Africa. In fact, assuming Africa as a single plate, since Greece is overriding Africa along the Hellenic trench is faster than Turkey along the Cyprean Arc (Figure 7). According to the model of McClusky et al. [9], on the basis of the velocity field in the Agean-Anatolian regions inferred from space geodetic data. Assuming that the Aegean Arc is moving faster $(30 \mathrm{~mm} / \mathrm{y})$ than the Anatolian peninsula $(24 \mathrm{~mm} / \mathrm{y})$. So, the movement variation between them is about $6 \mathrm{~mm} / \mathrm{y}$. If suppose that the Hellenic and Cyprean Arcs move towards the same direction, the displacement distance between two deepest point ( $\mathrm{A}^{\prime}$ and $\mathrm{B}^{\prime}$ ) or shallow points ( $\mathrm{A}$ and $\mathrm{B}$ ) is may be equivalent to about $0.56^{\circ}$ (about $61.6 \mathrm{~km}$ ). This displacement distance is assumed to be achieved in about 10 million years (Figure 6).

If no relative motion between Hellenic and Cyprean Arcs in Eastern Mediterranean occurs, the different convergent rates at the two subduction zones has to be related to differential 
velocities between hanging wall plates, responsible for the extension in between African plate and Anatolian block.

These results confirm that Eastern Mediterranean region consist of an assemblage of relatively small lithospheric blocks with a wide variety of rate strain release and thickness. This leads to the inevitability to study the seismic strain release at the Eastern Mediterranean region.

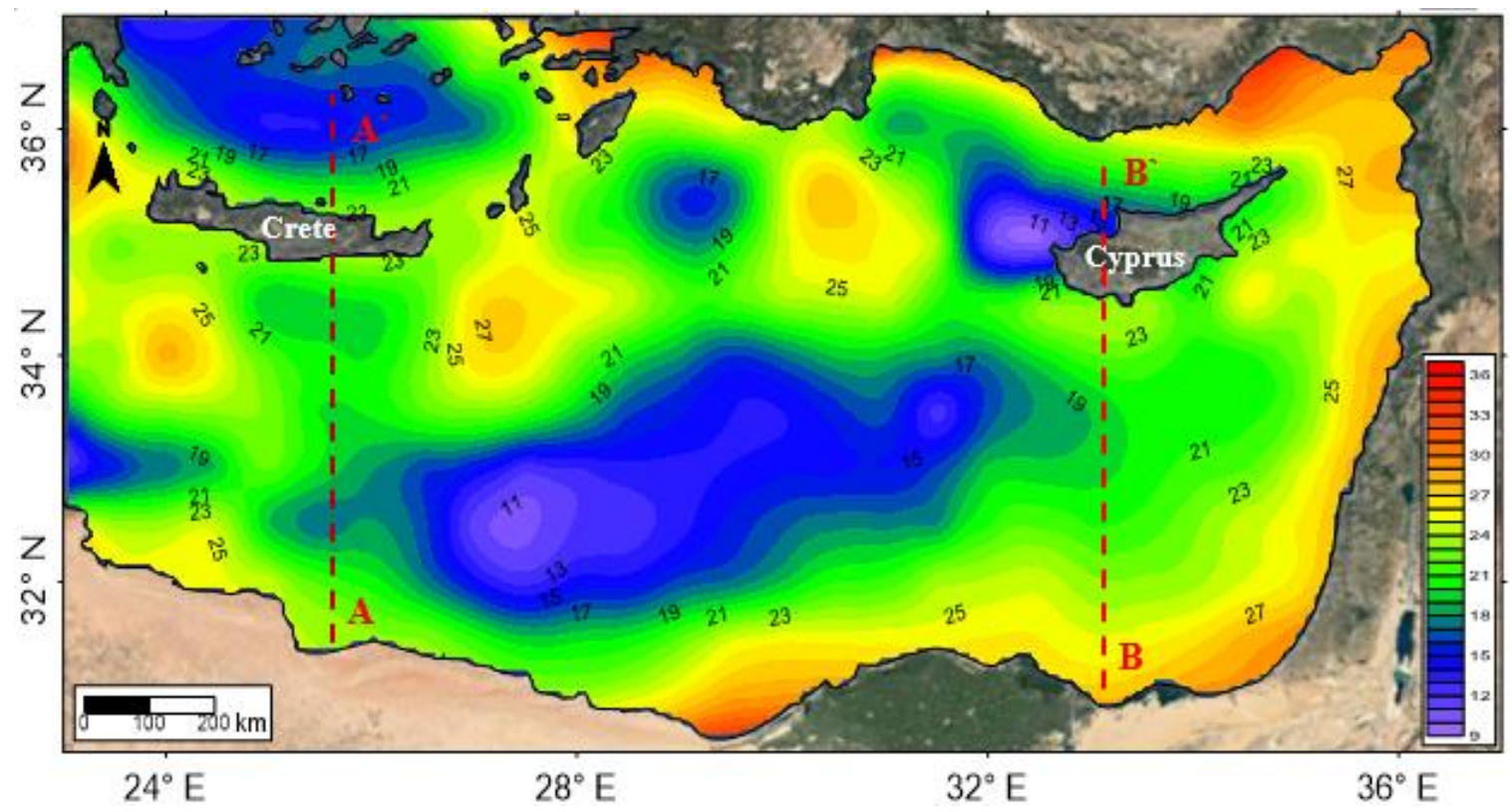

Figure 6. The crustal thickness of the Eastern Mediterranean Sea, Contour interval is $2 \mathrm{~km}$

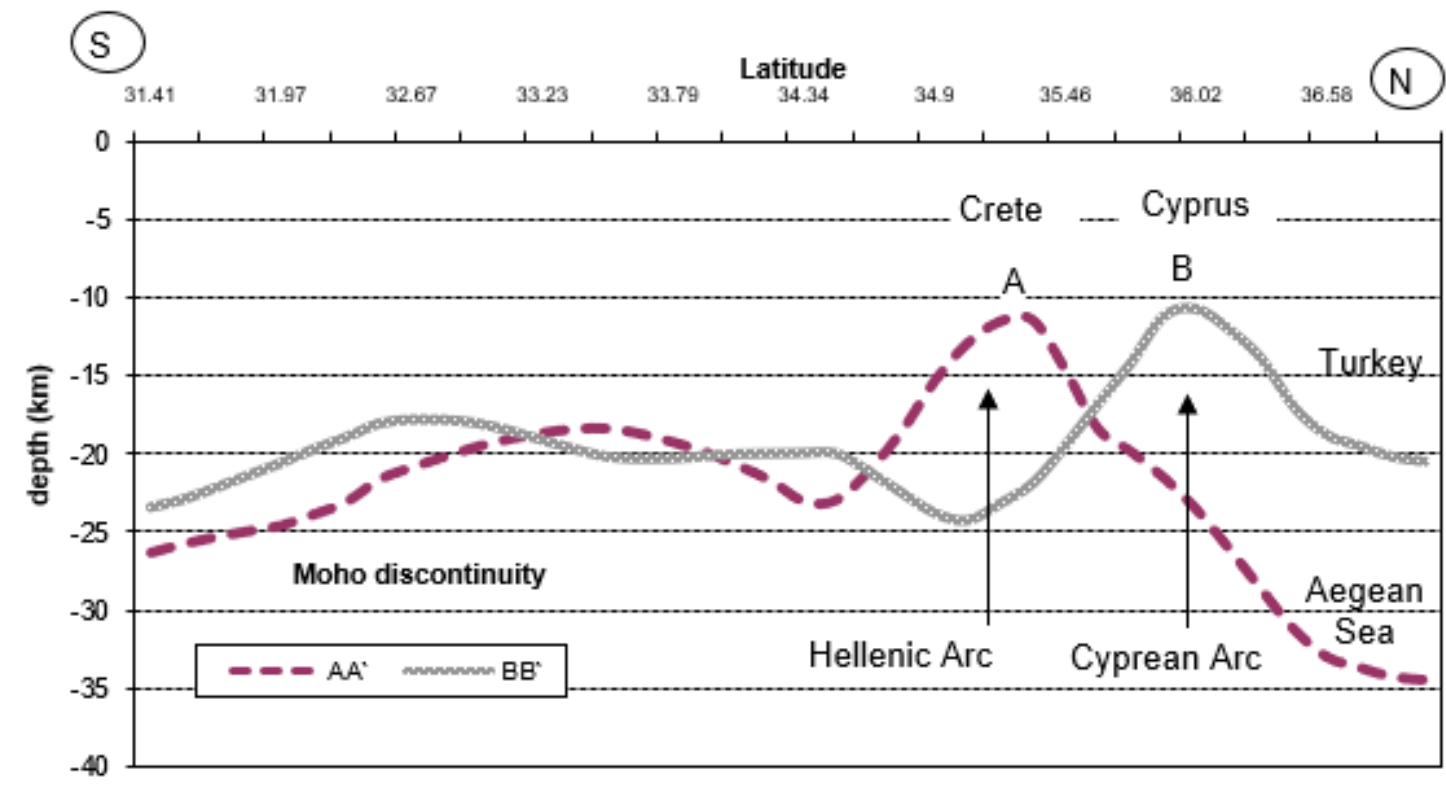

Figure 7. Correlation between the Moho discontinuities of the longitudinal profiles (NS direction) for the eastern and western sides of the Eastern Mediterranean Sea

\subsection{Seismic strain}

Figure (8) represent the resulting seismic strain rate in the Eastern Mediterranean Region, in units of $\mathrm{S}^{-1}$, for a total 214 seismic events with Ms in between 4 to 8 . Also represents the epicenters of the earthquakes included in these calculations. The subduction tectonics structure in the eastern Mediterranean between Africa, Greece, Anatolia, Eurasia and Arabia plates are characterized by variation of the seismic strain. Deformation is very active in the all area.

The largest seismic strain rate release $\mathrm{S}^{-1}$ is of order $10^{-14}$ observed in Hellenic Arc. The lower strain rate release of $10^{-}$ ${ }^{25}$ is observed in the front of the Egyptian Coast (African Plate).
The seismic stain release around Hellenic Arc $\left(10^{-14}\right)$ is relatively higher than the Cyprean Arc $\left(10^{-17}\right)$. The seismic strain release is abruptly increase started from the Mediterranean Ridge towards the Aegean Sea where the maximum values located along the Hellenic Arc. Also, there are some clusters in the southern and northern Crete, which have high seismic strain release. It is may be related to variation or relative motion between rigid blocks in this area. These variations of strain release may have relation to the forces which involved in deformation. On other side the abruptly increase started directly southern to the margin of Cyprus (Cyprean Arc). 


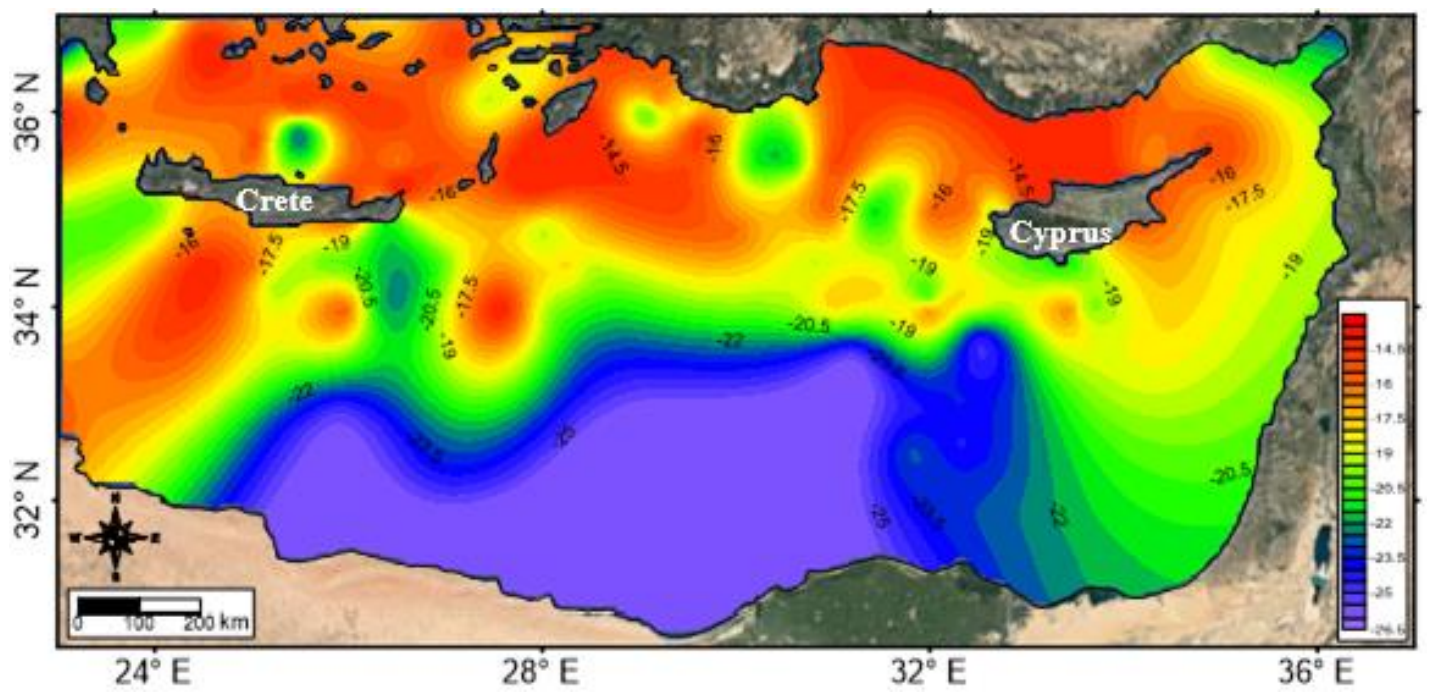

Figure 8. The calculated seismic strain rate in the Eastern Mediterranean Region related to the available seismicity data of the NEIC catalog, 1903-2017

\subsection{Salt tectonics}

There are two hypotheses in order to explain the origin of the observed stress variations along the Nile fan deposit (NFD) related to the salt tectonics. The first hypothesis indicated that the observed margin normal stress orientations in the suprasalt layers could be the result of down slope gravity gliding of salt bodies inducing essential pull strength in the sediments [37]. It remains unclear whether such a mechanism is plausible and whether it can explain the observed stress orientations. The second hypothesis based on the effect of the Messinian evaporites causing scattered stress orientations. While both hypotheses present plausible explanations and both favorable and opposing arguments are discussed by Tingay et al. [37], quantitative evidence to support either possibility is not presented.
Nile Delta is characterized by both typical deltaic structures (e.g. listric-growth faults and rotational block faults). These faults structures are associated by salt (such as normal and strike-slip faults, folds, collapsed depocenters, and polygonal mini-basins). This are observed as sequences above Messinian evaporates [5]. The presence of these structures affect the area through, (i) Salt layer mobility; (ii) Propagated sediments overloading on the slop; (iii) The presence of the sedimentary layers within evaporits layers that increases its density and improve its strength (Figure 9). The major fault blocks series found in the study area were growth faults (NE-SW) trending and mainly seaward throwing. The extensional stress resulted from the mass movement of mobile sediments on the upper and lower slopes. The studied growth faults are characterized by fault planes that dip seawards.

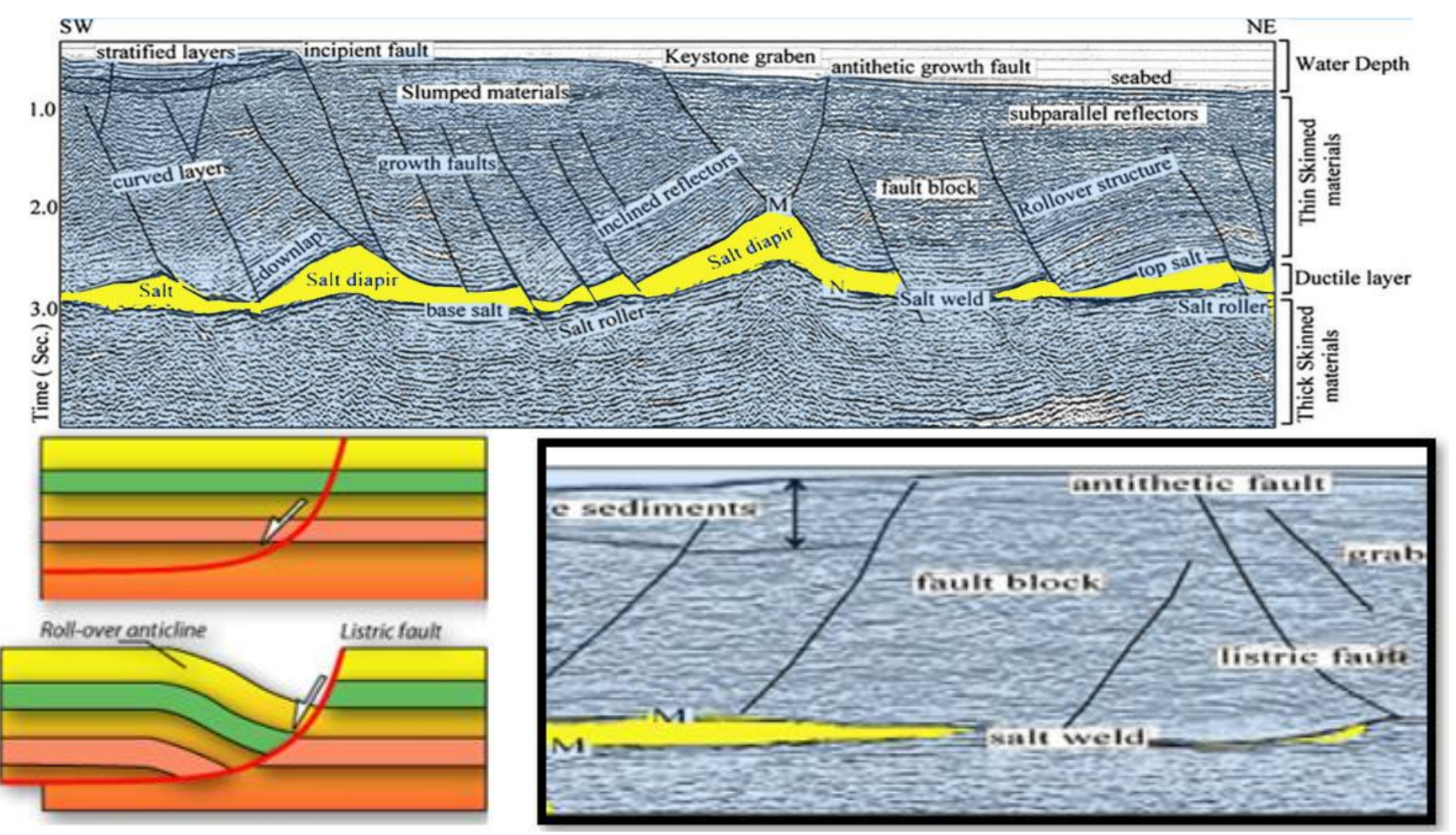

Figure 9. Seismic interpretation of Seismic interpretation of NE-SW \& EW and explain of the sketch of Listric fault 
Normal growth faults are commonly listric faults which can be identified by their dip and flattens with depth (Figure 9). Movements along this type of faults usually resulted in the formation of several types of structural traps. Growth faults are characterized by brittle rocks which overlie ductile rocks (salt) in under system of expanded pressure. The flattening of normal faults may reflect an increase in the ductility of rocks with increasing depth (Figure 9). Deformation may occur due to tilting of blocks. Listric normal faults were formed during the drifting of the passive continental margins and confined to the sedimentary prism forming these common features that characterized the passive margins. The growth faults seem to move due to the flow of the base deposits of the underlying ductile salts [38] (Figure 9).

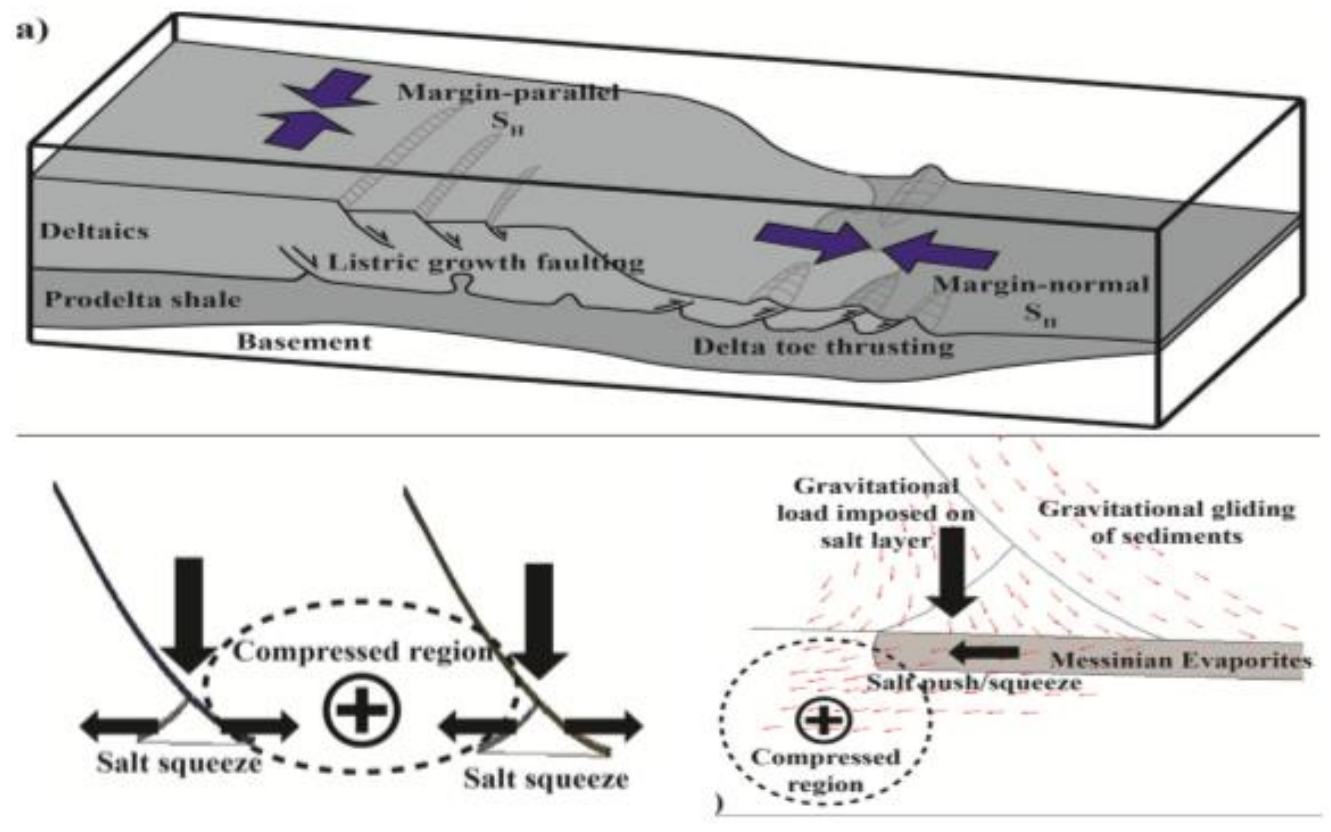

Figure 10. a) Typical stress field distribution of a deltaic system showing margin-parallel SH orientation in an extensional stress regime for the delta shelf region (near the continent) and margin-normal SH orientation in a compressive stress regime for the delta toe region (Figure adapted from Tingay et al. [17]). b) Synoptic diagram showing that the vertical load imposed on the salt pyramids squeezes the salt laterally, hence compressing the regions between the salt pyramids. The salt is both loaded vertically

(by the gravitational gliding of the sediments) and laterally (the resulting displacement vectors show that the salt is pushed laterally along the negative $\mathrm{x}$-direction) resulting in a region that undergoes localized compression [39]

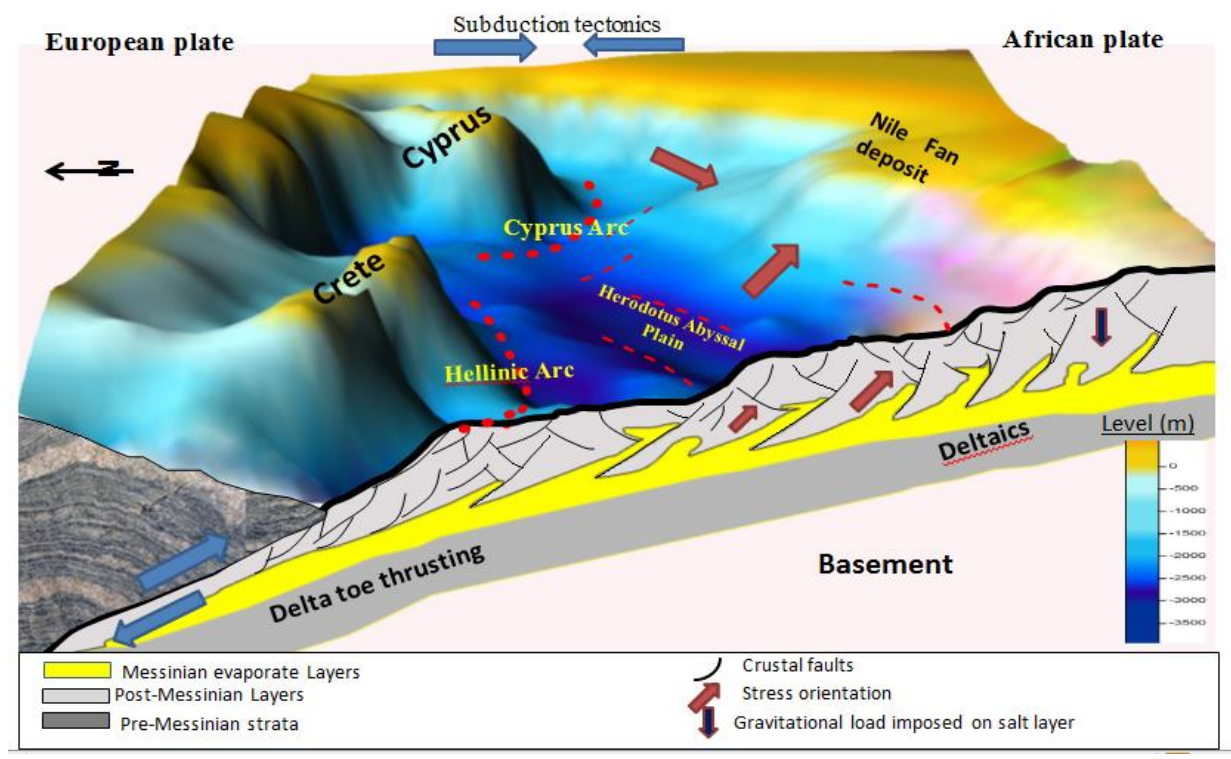

Figure 11. Illustration model and intersection from southwest to northeast of the Nile Delta, Geological structure types and bedding sequences

A series of listric, NNE-SSW trending normal faults divide the overburden sequences above evaporites into blocks ranging from $10-50 \mathrm{~km}$ in length. Channel systems formed within these blocks were either disrupted or guided by the faulting movement, suggesting recent faulting activity [5]. The
NW-SE bounding listric faults are, in general, gradually losing rotational tendencies in the northwest edge of the delta province and are replaced progressively by en echelon grabens [3] (Figure 10). The listric faulting pattern is interrupted by en echelon grabens. 
The primary driving force for salt tectonics is differential loading, forced displacement of one edge of salt body against the other edge, or by a thermal gradient. The salt flow could be resisted by two factors; (i) the force of the overburden, (ii) the pull along the boards of the evaporate body. The movement of the salt depends on the exceeding of the leading forces on the impedance to flow. The tectonism of salt is mainly related to regional deformation due to its weakness. During the stretching of faults the diapirs use the created space to rise up As the salt layers depleted the diapirs will fall and continue to widen. The salts may rise into the center of anticlines folds to form the salt domes. In other cases if the salt layers do not have the facility to develop passive salt structures, the salt may still move toward the low pressure areas around developing folds and faults in this case it describe as reactive (Figure 10).

In the Nile Delta region the main salt related structures tend perpendicular to the slop line of the Nile cone. These salt structures driven by gravity gliding and spreads due to sediment loading above the Messinian salt layers. While, the second salt structures type is of that features that indirectly cut across the continental slope of the Nile deep-sea fan. The suggested model shows the deformed stress structure under the Nile fan deposit is related to the main subduction tectonic structure while the fault-block movement is related to the impacts of strike-slip movements and growing salt diapirs (Figure 11). The north-western side of the Nile deep fan deposit is characterized by the formation of a series of salt folds and reverse faults above the Messinian evaporites which related to the compressional/subduction tectonics of the adjacent Mediterranean Ridge. While the north-eastern side of the Nile deep fan deposit characterized by forming small folds and tight diapirs, then a scarp of $400 \mathrm{~m}$ height around the Eratosthenes Seamount, corresponding to the basin ward limit of salt deformation [39].

\section{CONCLUSION}

The gravity anomalies in the eastern Mediterranean were varied from -40 (Anatolian) to 210 mgals (Herodotus Abyssal Plain). Aegean Sea and the North West Cyprus are nearly around 180 mgals. The clusters which have abrupt changing in the gravity anomalies may be related to changing in sediment thickness (i.e. between Cyprus and Crete) in addition to the changing of the crustal thickness and/or may be related to abrupt changing from continental to oceanic type (i.e. Aegean Sea).

The asymmetry of crustal thickness between the eastern and western sides of the Eastern Mediterranean could be attributed to the variation of the crustal movement at each side (Cyprean and Hellenic Arcs). The most deformed area lies nearly in between $34^{\circ}$ to $36.5^{\circ}$, around the Cyprean and Hellenic Arcs, where the main trend of deformation affects and extends to the north. The highly deformed area represented by tectonic activity of the Cyprean and Hellenic Arcs. The variation in crustal thickness is not only observed along each side but also across them.

The thick-skinned plate tectonic structures and thin-skinned salt tectonic control fluid dynamics along the fan deposit of the Nile Delta. These activities are associated with many clusters of mud volcanism along the southern part of the Hellenic and Cyprus arcs which separates both basins. Beside the platetectonic processes such as thin-skinned salt tectonics is evident at the Nile fan deposit (NFD). The evaporites creep down dip driven by gravity. The thin-skinned extension along the NFD and salt squeezing facilitate fluid flow through and out of the salt. The fluid or mud flows have impact on the upper layer (salt layer), that leads to create intrusion trenches into the upper thickness Pliocene-Quaternary sediments, which forms subduction morphological subduction zone (Hellenic and Cyprean Arcs).

The salt bodies along the study area presented in isolated salt pyramids, localized stress variations occur due to the mechanical property contrast between the creep salt and the elastic sediment blocks. Due to the gravitational gliding the salt is "squeezed out" laterally and compresses the adjacent elastic sediment blocks. The gravitational gliding occurs and a basal drag force induces related to the extension of continuous salt layer where this force is induced in the suprasalt layers. This approved by the suggested modeling results which provide additional quantitative evidence to confirm the observations from Tingay et al. [17] study. This explains the mechanical property contrast and basal drag effects that can lead to the reorientation of the stress field and the elevation of stress magnitudes in certain regions. This may exert significant influence to the operation of oil/gas exploration and exploitation. In the context of the discovery of the 30 trillion cubic feet gigantic "Zohr" gas field in the supra-salt region in the northeast Nile Delta.

\section{REFERENCES}

[1] Badawy A, Mohamed G, Omar K, Farid W. (2014). The northern Egyptian continental margin. Journal of African Earth Sciences 101: 177-185. http://dx.doi.org/10.1016/j.jafrearsci.2014.09.009

[2] Hamouda AZ, El-Gharabawy S, Awad M, Shata M, Badawi A. (2014). Characteristic properties of seabed fluvial-marine sediments in front of Damietta promontory, Nile Delta, Egypt. The Egyptian Journal of Aquatic Research 40: 373-383. http://dx.doi.org/10.1016/j.ejar.2014.11.006

[3] Marten R, Shann M, Mika J, Rothe S, Quist Y. (2004). Seismic challenges of developing the pre-Pliocene Akhen field offshore Nile Delta. The Leading Edge 23: 314-320. http://dx.doi.org/10.1190/1.1729228

[4] Abdel Aal A, El Barkooky A, Gerrits M, Meyer H, Schwander M, Zaki H. (2001). Tectonic evolution of the eastern Mediterranean basin and its significance for hydrocarbon prospectively in the ultra-deep water of the Nile Delta. The Leading Edge 19(10): 1086-1100. http://dx.doi.org/10.1190/1.1438485

[5] Loncke L, Gaullier V, Mascle J, Vendeville B, Camera L. (2006). The Nile deep-seafan: an example of interacting sedimentation, salt tectonics, and inherited subsalt paleotopographic features. Mar. Pet. Geol. 23(3): 297-315. https://doi.org/10.1016/j.marpetgeo.2006.01.001

[6] Loubrieu B, Satra C, Cagna R. (2001). Morphobathymetric and Backscatter Images of the Eastern Mediterranean Sea and Surroundings. Two sheets, Ifremer-CIESM, special publication, series Maps and Atlas.

[7] Loncke L, Gaullier V, Droz L. Ducassou E, Migeon S, Mascle J. (2009). Multi-scale slope instabilities along the Nile deep-sea fan, Egyptian margin: Ageneral overview. Marine and Petroleum Geology 26(5): 633-646. 
http://dx.doi.org/10.1016/j.marpetgeo.2008.03.010

[8] Hamouda AZ. (2010). A reanalysis of the AD 365 tsunami impact along the Egyptian Mediterranean coast. Acta Geophysica 58(4): 1-18 http://dx.doi.org/10.2478/s11600-009-0032-7

[9] McClusky S, Balassanian S, Barka A, Demir C, Ergintav S, Georgiev I, Gurkan O, Hamburger M, Hurst K, Khale H, Kastens K, Kekelidze G, King R, Kotzev V, Lenk O, Mahmoud S, Mishin A, Nadariya M, Ouzounis A, Paradissis D, Peter Y, Prilepin M, Reilinger R, Sanli I, Seeger H, Tealeb A, Toksoz M N, Veis G. (2000). Global positioning system constrains on plate kinematics and dynamics in the eastern Mediterranean and Caucasus. Journal of Geophysics Research 105: 5695-5719. https://doi.org/10.1029/1999JB900351

[10] Chamot-Rooke N, Rangin C, Pichon X. (2005). Crustal cross-sections across central Mediterranean. Mémoires de la Société géologique de France 177: 49-53.

[11] Hamouda AZ. (2010). Worst scenarios of tsunami effects along the Mediterranean coast of Egypt. Marine Geophysics Research 31(3): 197-214. http://dx.doi.org/10.1007/s11001-010-9099-4

[12] Faccenna C, Becker TW, Lucente FP, Jolivet L, Rossetti F. (2001). History of subduction and back-arc extension in the Central Mediterranean. Geophysical Journal International 145(3): 809-820. http://dx.doi.org/10.1046/j.0956-540x.2001.01435.x

[13] Shaaban F, Lutz R, Littke R, Bueker C, Odisho K. (2006). Source rock evaluation and basin modelling in NE Egypt (NE Nile Delta and Northern Sinai). Journal of Petroleum Geology 29: 103-124. http://dx.doi.org/10.1111/j.1747-5457.2006.00103.x

[14] Rashid A, El-Gharabawy S, Abou Shagar S. (2018). Geological and structural evaluation on temsah gas field, ne-offshore Nile Delta, Egypt. International Journal of Scientific Engineering and Applied Science 4(7): 18-29.

[15] Hamouda AZ. (2006). Numerical computations of 1303 tsunamigenic propagation towards Alexandria, Egyptian Coast. Journal of African Earth Science 44: 37-44. http://dx.doi.org/10.1016/j.jafrearsci.2005.11.005

[16] Bosworth W. (2006). North Africa-Mediterranean present-day stress field transition and implications for fractured reservoir production in the eastern Libyan basins. Geol. East Libya 4: 123-138.

[17] Tingay M, Bentham P, De Freyter A, Kellner A. (2011). Present-day stress-field rotations associated with evaporites in the offshore Nile Delta. AAPG Bull.123: 1171-1180. http://dx.doi.org/10.1130/B30185.1

[18] Heidbach O, Tingay M, Barth A, Reinecker J, Kurfeß D, Müller B. (2008). The World Stress Map Database Release 2008. http://dx.doi.org/10.1594/ GFZ.WSM.Rel2008. Available at: http://dc-app314.gfz-potsdam.de/pub/poster/ World_Stress_Map_Release_2008.pdf

[19] Tenveen JH, Woodside JM, Zitter TAC, Dumont JF, Mascle J, Volkonskaia A. (2004). Neotectonic evaluation of the Anaximander Mountains at the junction of the Hellenic and Cyprus arcs. Tectonophysics 391: 35-65.

[20] Hamouda AZ. (2006). Seismic hazard of Eastern Mediterranean. Journal of Acta Geophysics 54(2): 163 173. http://dx.doi.org/10.2478/s11600-006-0013-z

[21] Xiaodong P, Xinguang W, Luyi T, Hua L, Hao L, Xindong L, Yuxi C. (2015). A new method for deliverability evaluation of offshore gas reservoir with high temperature and pressure. Environmental and Earth Sciences Research Journal 2(1): 1-6. http://dx.doi.org/10.18280/eesrj.020101

[22] Kafisanwo O, Falade A, Bakare O, Oresanya A. (2018). Reservoir characterization and prospect identification in Onka field, offshore, Niger Delta. Environmental and Earth Sciences Research Journal 5(4): 79-86. https://doi.org/10.18280/eesrj.050401

[23] Makris J. (1977). Geophysiocal investigation of the Hellenides. Hamurger geophysics Einzelschr 34: 124.

[24] Woodside JM, Williams SA. (1977). Geophysical data report of the Eastern Mediterranean Sea. RRS Shackleton Cruise 3/72, 5/72, 1/74. Cambridge University, Dept. of Geodesy and Geophysics, 238.

[25] Allan TD, Morelli C. (1971). A geophysical study of the Mediterranean Sea. Boll. Geofis. Teor. Appl. XIII (50): 99-142.

[26] Markris J, Stobbe C. (1984). Physical properties and state of the crust and upper mantle of the eastern Mediterranean Sea deduced from geophysical data. Marine Geology 55: 217-254.

[27] Makris J, Wang J. (1994). Bouguer gravity anomalies of the Eastern Mediterranean Sea. Inst. Geoph. Univ. Hamburg, 87-99.

[28] Spiegel MR. (1972). Theory and problems of statistics (Schaum's Outline Series). McGraw Hill, NY.

[29] Mooney WD, Laske G, Guy Masters T. (1998). CRUST 5.1: A global crustal model at $5^{\circ} \times 5^{\circ}$. JGR Solid Earth 103(B1): 724-747.

[30] Ginzburg A, Makris J, Fuchs K, Prodehl C, Kaminski W, Amitai U. (1979). A seismic study of the crust and upper mantle of the Jordan-Dead Sea Rift and their transition toward the Mediterranean Sea. JGR Solid Earth 84(B4): 1569-1582.

[31] kostrov V. (1974). Seismic moment and energy of earthquakes, and seismic flow of rock, Izv. Acad. Sci. USSR Phys. Solid Earth 1: 23-44.

[32] Ekstrom G, Dziewonski AM. (1988). Evidence of bias in estimations of earthquakes size. Nature 332: 319-323.

[33] Le Pichon X, Lallemant SJ, Chamot-Rooke N, Lemeur D, Pascal G. (2002). The Mediterranean ridge backstop and the Hellenic nappes. Marine Geology 186: 111-125. http://dx.doi.org/10.1016/S0025-3227(02)00175-5

[34] Wortel MJR, Spakman W. (2000). Subduction and slab detachment in the Mediterranean-Carpathian region. Science 290: 1910-1917. http://dx.doi.org/10.1126/science.290.5498.1910

[35] Jimenez-Munt I, Sabadini R, Gardi A. (2003). Active deformation in the Mediterranean from Gibraltar to Anatolia inferred from numerical modeling and geodetic and seismological data. Journal of Geophysical Research 108 (B1): ETG 2-1-ETG 2-24, http://dx.doi.org/10.1029/2001JB001544

[36] Angelier J, Tarantola A, Manoussis S, Valette B. (1982). Inversion of field data in fault tectonics to obtain the regional stress. Geophysical Journal of the Royal Astronomical Society 69: 607-621.

[37] Tingay M, Bentham P, De Freyter A, Kellner A. (2012). Evidence for non-Andersonian faulting above evaporites in the Nile Delta. Geological Society, London, Special Publications 367: 155-170. http://dx.doi.org/10.1144/SP367.11

[38] Imber J, Chiuld C, Nell P, Walsh J, Hodgetts D, Flint S. (2003). Hanging wall fault kinematic and footwall 
collapse in listric growth fault system. J Struct Geol 25: 197-20. http://dx.doi.org/10.1016/S01918141(02)00034-2

[39] Eckert A, Zhang W. (2016). Salt geometry influence on present-day stress orientations in the Nile Delta: Insights from numerical modeling. Journal of African Earth

Sciences 114 : 96-109. http://dx.doi.org/10.1016/j.jafrearsci.2015.11.014 